Desak Putu Kristian Purnamiasih, Nani Nurhaeni, Siti Chodidjah

Aplikasi Model Adaptasi Roy Pada Anak Dengan Gangguan Keseimbangan Cairan

\title{
APLIKASI MODEL ADAPTASI ROY PADA ANAK DENGAN GANGGUAN KESEIMBANGAN CAIRAN
}

\author{
Desak Putu Kristian Purnamiasih ${ }^{1}$, Nani Nurhaeni ${ }^{2}$, Siti Chodidjah ${ }^{3}$ \\ ${ }^{1)}$ Akademi Keperawatan Ngesti Waluyo Parakan \\ ${ }^{2), 3)}$ Fakultas Ilmu Keperawatan Universitas Indonesia
}

Korespondensi penulis: deskjazz@yahoo.co.id

\begin{abstract}
Abstrak
Cairan berfungsi dalam penyerapan nutrisi, proses metabolisme, fungsi sel - sel tubuh, dan organ tubuh. Gangguan keseimbangan cairan pada sistem gastrointestinal dapat disebabkan oleh diare, muntah atau perdarahan. Aplikasi model adaptasi Roy bertujuan untuk mendukung pasien mampu berespon secara adaptif terhadap gangguan kesehatannya. Empat dari lima klien kelolaan yang mengalami gangguan keseimbangan cairan mengalami keberhasilan adaptasi terhadap gangguan keseimbangan cairan mereka. Sementara, satu klien kelolaan lainnya pada awalnya mengalami perbaikan tetapi adanya penyakit penyerta lainnya menyebabkan klien tidak dapat beradaptasi. Keberhasilan adaptasi individu dipengaruhi oleh usia klien, temperatur lingkungan, stress, dan tingkat keparahan penyakit. Kemampuan perawat mengelola stimulus yang mempengaruhi keseimbangan cairan akan meningkatkan kemampuan adaptasi klien dalam menghadapi gangguan kesehatannya.
\end{abstract}

Kata Kunci: adaptasi; keseimbangan cairan; sistem gastrointestinal

\section{PENDAHULUAN}

Komponen utama dari tubuh manusia adalah air, yang merupakan $55 \%-60 \%$ dari berat badan pada orang dewasa, $60 \%-65 \%$ pada anak, dan $75 \%-80 \%$ pada bayi. Cairan berfungsi dalam membantu penyerapan nutrisi dan metabolisme dalam tubuh, dan elektrolit sangat penting untuk fungsi dari sel-sel dan organ tubuh karena sifatnya sebagai ion tubuh (James, Nelson, \& Ashwill, 2013).

Pada kondisi sakit, kehilangan cairan tubuh manusia diakibatkan oleh: kehilangan cairan melalui saluran cerna (muntah, diare, perdarahan); kehilangan cairan melalui kulit (luka bakar, diaforesis), serta kehilangan cairan karena fungsi ginjal terganggu (Wong, Hockenberry, Wilson, Winkelstein
\&Schwartz, 2009). Diare menimbulkan dehidrasi pada anak maupun kondisi asidosis metabolik (Silbernagl \& Lang, 2006).

Penelitian yang dilakukan oleh Begum, Hoque, Hussain, Hasan, dan Molla (2010) pada anak usia 1-44 bulan yang mengalami diare akut menunjukkan bahwa hipokalemia dan hiponatremia adalah hasil abnormal yang banyak ditemukan. Anak-anak penderita gizi buruk kelompok umur 6-24 bulan yang mengalami diare dan muntah, pada suatu penelitian ditemukan lebih banyak mengalami hiponatremia $(\mathrm{p}=0,019)$ dan hipokalemia $(\mathrm{p}=0,018) \quad$ (Gangaraj, Das, \& Madhulata, 2013).

Anak yang mengalami diare di ruang rawat infeksi anak di RSUPN DR. Cipto Mangunkusumo pada 
Desak Putu Kristian Purnamiasih, Nani Nurhaeni, Siti Chodidjah

Aplikasi Model Adaptasi Roy Pada Anak Dengan Gangguan Keseimbangan Cairan

umumnya disertai juga dengan penyakit lainnya. Asuhan keperawatan komprehensif diperlukan karena gangguan keseimbangan cairan, dan elektrolit dipengaruhi oleh stimulus yang bersifat langsung maupun tidak langsung sehingga mempengaruhi adaptasi seluruh fungsi organ tubuh anak, adaptasi konsep diri, peran diri, dan ketergantungan anak terhadap keluarga maupun orang lain.

Aplikasi model adaptasi Roy berfokus pada stimulus lingkungan, dan respon bio-psiko-sosial terhadap stimulus, serta menekankan interaksi antara individu, dan lingkungan (Christensen \& Kenney, 2009). Tugas perawat dalam mendukung pasien untuk mampu berespon secara adaptif terhadap kondisi gangguan keseimbangan cairan adalah melalui proses asuhan keperawatan menggunakan aplikasi model adaptasi Roy. Kemampuan menganalisa respon, dan stimulus akan dapat menentukan intervensi keperawatan yang tepat, sehingga tercapai kemampuan adaptasi yang diinginkan. Hal ini yang menjadi latar belakang penggunaan model adaptasi Roy dalam memberikan asuhan keperawatan pada anak yang mengalami gangguan keseimbangan cairan di RSUPN DR. Cipto Mangunkusumo.

\section{METODE}

Metode penelitian ini adalah studi kasus melalui pemberian asuhan keperawatan. Jumlah responden yang dikelola berjumlah lima anak pada kelompok usia bayi sampai dengan remaja. Lima responden tersebut mengalami gangguan keseimbangan cairan karena diare, dan muntah sehingga menjalani perawatan di rumah sakit. Asuhan keperawatan diberikan dengan menggunakan aplikasi model adaptasi Roy. Proses asuhan keperawatan mulai dari pengkajian, menentukan diagnosa keperawatan, menetapkan tujuan, membuat intervensi keperawatan, dan evaluasi.

\section{HASIL}

Kasus 1, an. R, laki-laki, usia 10 tahun, diagnosa medis epilepsi, dan Tuberkulosis on OAT bulan ke-3. Diagnosa keperawatan terkait cairan pada an. $\mathrm{R}$ adalah risiko kekurangan volume cairan berhubungan dengan muntah dan peningkatan suhu tubuh.

Implementasi yang sudah dilakukan adalah mengobservasi tanda-tanda vital setiap 3 jam, memberikan minum air pada klien sedikit demi sedikit, menghitung intake, dan output cairan serta memberikan cairan parenteral KaEn 1B. Evaluasi didapatkan bahwa diagnosa pada klien teratasi.

Kasus 2, an. R, laki-laki, usia 4 bulan, diagnosa medis pasca laparatomi, ileostomi + kolostomi double barrel e.c invaginasi ileocolica, riwayat high output stoma. Diagnosa keperawatan terkait cairan pada an. $\mathrm{R}$ adalah risiko kekurangan volume cairan berhubungan dengan peningkatan produksi stoma.

Implementasi yang sudah dilakukan adalah mengukur tandatanda vital, dan tanda-tanda dehidrasi, meminta ibu klien untuk memberikan ASI, menimbang berat badan klien setiap hari, mengukur intake, dan output cairan. Klien juga diberikan cairan parenteral KaEn 1B, ASI ditambah SF 8 x 60 ml. Evaluasi 
Desak Putu Kristian Purnamiasih, Nani Nurhaeni, Siti Chodidjah

Aplikasi Model Adaptasi Roy Pada Anak Dengan Gangguan Keseimbangan Cairan

didapatkan bahwa diagnosa yang muncul pada klien teratasi.

Kasus 3, an. A, laki-laki, usia 15 tahun, dengan diagnosa medis tuberkulosis abdomen. Diagnosa keperawatan terkait cairan pada an.A adalah kekurangan volume cairan berhubungan dengan kehilangan cairan dan elektrolit melalui diare, dan muntah. Implementasi yang sudah dilakukan pada an.A adalah mengukur tanda-tanda vital, menghitung intake dan output cairan, menimbang berat badan. Tindakan kolaborasi yang diberikan pada klien adalah memberikan cairan parenteral $\mathrm{N} 5+\mathrm{Kcl}(10)$, memberi peptamen dan F100 modifikasi. Evaluasi didapatkan bahwa diagnosa yang muncul pada klien tidak teratasi.

Kasus 4, an. K, perempuan usia 1,5 tahun, dengan diagnosa medis pneumonia komunitas, dan diare akut. Diagnosa keperawatan terkait cairan pada an. $\mathrm{K}$ adalah kekurangan volume cairan berhubungan dengan kehilangan cairan, dan elektrolit tubuh, serta intake cairan tidak adekuat.

Implementasi yang sudah dilakukan adalah mengukur tandatanda vital setiap 3 jam, mengkaji tanda-tanda dehidrasi, mengukur intake dan output cairan, memberikan cairan intravena KaEn 3B $35 \mathrm{ml} / \mathrm{jam}$, memberi klien minum melalui NGT, menimbang berat badan klien setiap hari. Evaluasi didapatkan bahwa diagnosa keperawatan yang muncul pada klien teratasi.

Kasus 5, an. H, perempuan, usia 3 bulan, dengan diagnosa medis pneumonia komunitas, dan diare akut. Diagnosa keperawatan terkait cairan yang muncul pada an. $\mathrm{H}$ adalah kekurangan volume cairan berhubungan dengan muntah, dan diare.

Implementasi yang sudah dilakukan pada an. $\mathrm{H}$ adalah mengukur tanda-tanda vital, mengobservasi tanda-tanda dehidrasi, mengukur intake dan output cairan, memberikan renalit, memberi SF 90 cc setiap kali pemberian, menimbang berat badan setiap hari. Pada evaluasi didapatkan bahwa diagnosa keperawatan yang muncul pada klien teratasi.

\section{Aplikasi Teori Keperawatan Pada Kasus Terpilih}

Konsep asuhan keperawatan menggunakan aplikasi model adaptasi Roy akan digambarkan pada skema berikut:

\section{INPUT}
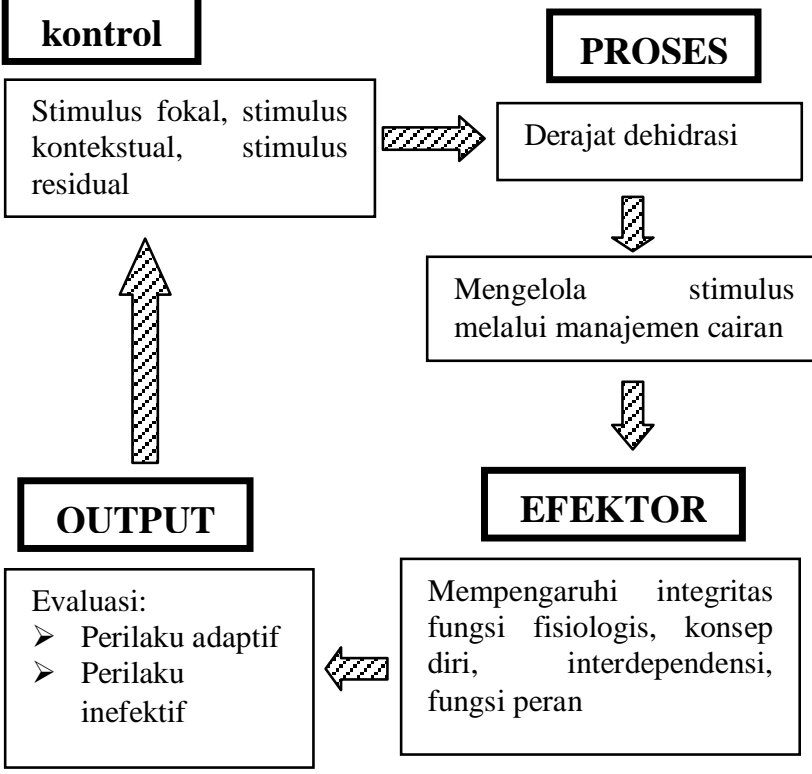

Skema 1. Konsep Asuhan

Keperawatan Berdasarkan Roy Adaptation Model

Kasus yang dipilih adalah an. K, perempuan usia 1,5 tahun, dengan 
diagnosa medis pneumonia komunitas dan diare akut. Pada pengkajian perilaku model adaptasi fisiologis terkait cairan didapatkan data bahwa klien BAB cair dari pagi $5 \mathrm{x}$ warna kuning dan ada lendir, warna urin kuning pekat, hasil pemeriksaan urin lengkap: kuning agak keruh, klien gelisah, rewel. Turgor kulit sedang, mukosa bibir kering. Hasil pemeriksaan laboratorium: natrium $140 \mathrm{mEq} / \mathrm{L}$, kalium 3,4 $\mathrm{mEq} / \mathrm{L}, \quad$ klorida 99 $\mathrm{mEq} / \mathrm{L}$, ca $7,6 \mathrm{mg} / \mathrm{dl}$, fosfat inorganik $2,8 \mathrm{mg} / \mathrm{dl}$. Pada pengkajian perilaku model adaptasi interdependensi, dan konsep diri didapatkan data bahwa klien saat ini rewel, dan sangat tergantung sepenuhnya pada ibunya.

Pada pengkajian stimulus model adaptasi fisiologis terkait cairan didapatkan data bahwa stimulus fokal: kehilangan cairan dan elektrolit tubuh, serta intake cairan tidak adekuat. Stimulus kontekstual: diare meningkatkan kehilangan cairan, dan elektrolit, sedangkan sesak napas meningkatkan penggunaan cairan untuk metabolisme tubuh.

Pada pengkajian stimulus model adaptasi interdependensi didapatkan data bahwa stimulus fokal: klien merasa lelah, dan tidak bisa beraktivitas seperti biasanya. Pada pengkajian stimulus model adaptasi konsep diri didapatkan data bahwa stimulus fokal: kelemahan tubuh.

Diagnosa keperawatan terkait cairan yang muncul pada klien adalah kekurangan volume cairan berhubungan dengan kehilangan cairan melalui diare. Tindakan keperawatan yang telah dilakukan, mengukur tanda - tanda vital, menilai turgor kulit, dan tingkat kesadaran klien, mengukur intake dan output cairan setiap shift, memberikan klien minum air melalui NGT, menganjurkan klien tetap diberikan ASI, menimbang berat badan klien setiap hari, memantau pemberian cairan parenteral KaEN 3B, memantau hasil lab terkait cairan. Evaluasi didapatkan bahwa kekurangan volume cairan pada klien teratasi.

Peran spesialis keperawatan anak sebagai care giver, client advocate, counsellor, Educator, collaborator, dan change agent dapat dilaksanakan oleh residen selama praktik residensi I, dan residensi II. Peran ini dilakukan melalui tindakan memberikan asuhan keperawatan menggunakan aplikasi model adaptasi Roy, memberikan penjelasan pada saat orang tua memutuskan bahwa anaknya akan dirawat di rumah walaupun kondisi anak belum baik. Tindakan lainnya adalah memberikan pendidikan kesehatan pada klien, dan keluarga, melakukan kerjasama dengan profesi kesehatan lainnya, memberikan asuhan keperawatan berdasarkan evidence based practice (James, Nelson, \& Ashwill, 2013).

\section{PEMBAHASAN}

Sumber yang paling umum dari peningkatan kehilangan cairan adalah saluran gastrointestinal dari muntah, diare, atau keduanya (misalnya, gastroenteritis). Sumbersumber lain adalah ginjal (misalnya, ketoasidosis diabetik), kulit (misalnya, keringat berlebihan, luka bakar). Penurunan asupan cairan sangat bermasalah ketika anak muntah, saat cuaca panas, dan ketika 
demam, takipnea, atau keduanya (Potts, \& Mandleco, 2012). Demam meningkatkan IWL sebanyak $12 \%$ setiap $1{ }^{\circ} \mathrm{C}$ kenaikan suhu tubuh (Behrman, Kliegman, \& Arvin, 2000). Parameter untuk menentukan derajat dehidrasi memerlukan pemantauan tanda-tanda vital, penampilan klinis, produksi urine dan berat jenis, berat badan, dan kadar elektrolit serum. (James, Nelson, \& Ashwill, 2013).

Pengkajian pada kasus kelolaan tentang gangguan keseimbangan cairan sangat berkesinambungan dengan menggunakan model adaptasi Roy. Pengkajian tentang gangguan keseimbangan cairan meliputi intake, dan rute pemenuhan cairan, turgor kulit, mukosa bibir, adanya edema/tidak, hasil pemeriksaan elektrolit, analisa gas darah. Cairan, dan elektrolit sebagai mediator dari sistem regulator akan mempengaruhi fungsi ginjal dalam mengatur keseimbangan cairan, dan asam basa.

Pengkajian tentang gangguan keseimbangan cairan menggunakan model adaptasi roy bersifat multifokal dengan dasar bahwa klien dipandang sebagai individu, dan makhluk bio-psiko-sosio-spiritual. Kondisi bio-psiko-sosio-spiritual mencakup banyak aspek sehingga memerlukan tugas yang sangat banyak bagi perawat untuk melakukan pengkajian. Pengetahuan perawat tentang patofisiologi penyakit, dan keterampilan dalam pengkajian sangat diperlukan dalam menggunakan model adaptasi Roy (Christensen \& Kenney, 2009).

Lima klien pada kasus kelolaan merupakan anak dalam berbagai kelompok usia. Dua klien termasuk kelompok usia bayi, satu klien termasuk kelompok toddler, sedangkan dua klien lainnya termasuk kelompok anak usia sekolah, dan remaja. Perilaku yang ditunjukkan dari hasil pengkajian pada kelima klien kelolaan menunjukkan perilaku yang berbeda sesuai dengan derajat dehidrasi, dan usia klien. Pada penelitian yang dilakukan oleh Whittemore, Jaser dan Guo (2010) tentang pengkajian pada anak dengan penyakit diabetes mellitus tipe 1 menunjukkan bahwa karakteristik usia, status sosial ekonomi, penggunaan alat-alat kesehatan, respon psikososial (gejala depresi dan respon kecemasan), dan fungsi keluarga mempengaruh adaptasi. Para pasien yang menjalani pengobatan dalam waktu yang lama dapat mengalami gangguan fisik seperti kelelahan, gangguan integritas kulit, gangguan cairan, dan elektrolit. Pengalaman dalam perubahan fisiologis dapat mempengaruhi fungsi peran pasien (interaksi sosial dengan teman sebaya), dan saling ketergantungan dengan keluarga (Bilal, Badr, \& AlAtiyyat 2014).

Diagnosa keperawatan ditentukan berdasarkan penilaian perilaku yang paling relevan dengan stimulus/rangsangan (Tomey \& Alligood, 2010). Diagnosa keperawatan tentang gangguan keseimbangan cairan yang muncul pada kasus kelolaan adalah diagnosa aktual, dan risiko. Diagnosa aktual tentang gangguan keseimbangan cairan adalah kekurangan volume cairan. Kekurangan volume cairan menurut Wilkinson dan Ahern (2009) adalah penurunan cairan intravaskular, interstisial, atau intrasel. Diagnosa ini merujuk pada 
Desak Putu Kristian Purnamiasih, Nani Nurhaeni, Siti Chodidjah

Aplikasi Model Adaptasi Roy Pada Anak Dengan Gangguan Keseimbangan Cairan

dehidrasi yang merupakan kehilangan cairan saja. Diagnosa risiko tentang gangguan keseimbangan cairan adalah risiko kekurangan volume cairan. Risiko kekurangan volume cairan menurut Wilkinson dan Ahern (2009) adalah kondisi individu yang beresiko mengalami dehidrasi vaskular, selular, atau intraselular.

Dehidrasi isonatremia (tingkat sodium dari 138-145 mEq/L), adalah bentuk paling umum dari dehidrasi pada anak yang disebabkan oleh muntah, diare, kehilangan cairan melalui pernapasan, sistem integumen, penurunan intake cairan per oral yang disertai peningkatan aktivitas (James, Nelson, \& Ashwill, 2013). Penelitian yang dilakukan oleh Begum, Hoque, Hussain, Hasan, dan Molla (2010) pada anak usia 144 bulan yang mengalami diare akut menunjukkan bahwa hipokalemia ditemukan pada $27 \quad(30,1 \%)$ responden, dan hiponatremia 13 $(15,1 \%)$ responden. Rata-rata natrium yang ditemukan pada penelitian tersebut adalah 135,3 meq/l (105-148 meq/l), dan rata-rata kalium 3,9 meq/l (1,5-5,7 meq/l). Anak-anak penderita gizi buruk kelompok umur 6-24 bulan yang mengalami diare dan muntah, pada suatu penelitian ditemukan lebih banyak mengalami hiponatremia $(\mathrm{p}=0,019)$ dan hipokalemia $(\mathrm{p}=0,018)$ dibandingkan dengan kelompok gizi buruk yang hanya mengalami muntah (Gangaraj, Das, \& Madhulata, 2013).

Pada lima kasus kelolaan, stimulus fokal yang menyebabkan kehilangan volume cairan adalah diare, muntah, dan intake yang tidak adekuat. Stimulus kontekstual adanya penyakit penyerta yaitu infeksi saluran pernapasan, infeksi pada saluran pencernaan, kondisi pasca operasi, dan demam. Perilaku inefektif yang ditemukan pada lima klien kelolaan akibat adanya stimulus tersebut adalah rasa haus, mata cekung, mukosa bibir kering, penurunan berat badan, mengeluh badan terasa lemah, gelisah, dan rewel. Pada pemeriksaan tanda-tanda vital didapatkan sebagian besar tanda-tanda vital klien dalam batas normal.

Perilaku inefektif juga ditemukan pada 1 klien kelolaan yaitu hasil pemeriksaan laboratorium elektrolit, dan analisa gas darah, walaupun pemeriksaan dilakukan pada hari sebelum pengkajian dilakukan. Empat klien kelolaan menunjukkan bahwa nilai laboratorium elektrolit masih dalam rentang nilai normal, sesuai dengan hasil penelitian Begum, Hoque, Hussain, Hasan, dan Molla (2010), dan sumber yang menyebutkan bahwa dehidrasi yang paling umum dialami anak karena diare, dan muntah adalah dehidrasi isonatremia (James, Nelson, \& Ashwill, 2013).

Tujuan yang dibuat oleh residen pada 5 kasus kelolaan melibatkan klien, dan keluarga mencakup perilaku yang hendak diubah menjadi adaptif, bentuk perilaku yang hendak diubah menjadi adaptif dengan melihat usia perkembangan anak, serta pengetahuan keluarga. Waktu untuk pencapaian tujuan dibuat dengan melibatkan klien, dan keluarga dengan mempertimbangkan usia anak, penyakit penyerta, dan kondisi anak pada saat dilakukan pengkajian. Waktu untuk pencapaian tujuan dibuat dengan melihat respon, 
dan kemauan keluarga sebagai faktor pendukung untuk kesembuhan klien (Tomey, \& Alligood, 2010).

Pencapaian tujuan memerlukan pemahaman yang baik dari klien maupun keluarga. Melalui peran perawat sebagai counsellor, dan educator, pemberian informasi tentang kondisi klien pada keluarga menjadi bagian yang penting bagi perawat dalam menetapkan tujuan bersama klien, dan keluarga. Keputusan yang diambil keluarga, dan klien dalam pencapaian tujuan memerlukan konseling yang baik dari perawat.

Intervensi yang dilakukan pada klien kelolaan menggunakan model adaptasi Roy bertujuan untuk mengelola stimulus, dengan cara menyingkirkan, meningkatkan, mengurangi, dan mengubah stimulus, sehingga individu dapat beradaptasi, dan menunjukkan perilaku adaptif (Christensen \& Kenney, 2009). Intervensi yang diberikan pada klien adalah untuk mencegah kejadian terulang kembali.

Intervensi terkait cairan yang diberikan pada klien kelolaan adalah memberikan cairan rehidrasi enteral, dan parenteral, menghitung intake, dan output cairan, menganjurkan ibu untuk tetap memberikan ASI, mengajarkan pemberian cairan oral melalui NGT dengan feeding tube, memberikan syrup Zinc, dan menimbang berat badan klien setiap hari.

Pemberian cairan rehidrasi enteral berdasarkan bukti penelitian, dapat mengurangi kematian akibat diare hingga 93\%, karena co transport glukosa dan natrium di seluruh lapisan epitel di usus halus mendukung efek perlindungan dari penggunaan rehidrasi oral terhadap kehilangan cairan dan elektrolit (Munos, Walker, \& Black, 2010). Intervensi ini merupakan tindakan untuk mengurangi stimulus, dengan cara pemberian glukosa, dan natrium untuk mempertahankan kondisi usus, dan mengganti kehilangan cairan.

Menghitung intake, dan output cairan serta menimbang berat badan dilakukan untuk menyingkirkan stimulus, yaitu menghindari klien terjadi kekurangan atau kelebihan cairan. Selama praktik, residen menerapkan family centered care dengan cara melibatkan keluarga untuk bekerjasama menghitung intake, dan output cairan melalui pencatatan di buku harian. Residen juga memberitahu ibu klien untuk tetap berusaha memberikan ASI, terutama pada klien usia bayi, walaupun klien mendapatkan susu formula juga di RS. Ibu pada dua klien kelolaan memang beralasan tidak memberikan ASI, karena ASI yang keluar sedikit, tetapi residen tetap memotivasi ibu klien untuk memompa ASI. Menurut penelitian, risiko kematian bayi akibat diare lebih tinggi pada bayi yang tidak mendapatkan ASI eksklusif dibandingkan dengan bayi yang mendapatkan ASI eksklusif (Lamberti, Walker, Noiman, Victora, \& Black, 2011). Bayi usia 9-11 bulan yang tidak disusui, kejadian infeksi rotavirus jauh lebih tinggi $(82 \%)$ dibandingkan dengan bayi dalam kelompok usia 0-5 bulan (57\%) (Dey et al., 2013).

Pemberian intervensi keperawatan pada kasus kelolaan menggunakan model adaptasi Roy secara umum mampu dikelola dengan baik karena stimulus yang 
menimbulkan perilaku inefektif sudah diketahui pada saat pengkajian. Pengelolaan stimulus dengan memberikan intervensi berdasarkan evidence based practice meningkatkan adaptasi klien terhadap gangguan keseimbangan cairan. Hambatan dalam aplikasi model adaptasi Roy dalam intervensi keperawatan secara umum adalah memerlukan pertimbangan berbagai aspek untuk menentukan intervensi yang tepat. Intervensi yang tepat memerlukan pengkajian yang lama, dan mendalam untuk mengetahui stimulus yang mempengaruhi perilaku inefektif.

Evaluasi pada 5 kasus kelolan tentang diagnosa keperawatan kekurangan volume cairan mencapai perilaku yang adaptif pada 4 klien kelolaan, sedangkan 1 klien meninggal karena syok hipovolemia. Waktu pencapaian perilaku adaptif pada 4 klien kelolaan berbeda-beda karena usia, penyakit penyerta, serta keterlibatan keluarga sebagai faktor pendukung. Intervensi yang diberikan residen untuk mengelola stimulus, melalui intervensi mandiri bersama keluarga, dan kolaborasi dengan profesi lain. Pengelolaan gangguan keseimbangan cairan tidak memerlukan waktu lama pada empat klien kelolaan, karena intervensi yang diberikan merupakan aplikasi dari evidence based practice. Evaluasi pada 1 klien kelolaan menunjukkan perilaku inefektif karena syok hipovolemia. Syok hipovolemia merupakan efek dari stimulus fokal, kontekstual, dan residual yang berlangsung sangat lama, sehingga untuk mengelola stimulus tersebut cukup sulit, walaupun intervensi yang diberikan sudah ditujukan untuk mengelola semua stimulus yang dihadapi klien.

Evaluasi menunjukkan bahwa tidak semua klien mencapai perilaku adaptif. Ketika perilaku adaptif tidak tercapai maka intervensi yang dilakukan terkait gangguan keseimbangan cairan adalah memberikan intervensi yaitu pemberian cairan parenteral dengan tetesan cepat menuju vena central. Pemberian cairan oral tidak dilakukan karena kondisi klien tidak memungkinkan untuk diberikan. Ketika loading cairan tidak mampu mengatasi kondisi syok hipovolemia, maka klien diberikan transfusi PRC. Kondisi syok mempengaruhi sirkulasi, dan tanda-tanda vital klien, untuk mempertahankan tanda-tanda vital klien yang mengalami penurunan, dilakukan pemberian dopamin, dan dobutamin.

\section{KESIMPULAN}

Aplikasi model adaptasi Roy dalam menangani masalah cairan pada anak berorientasi pada tujuan, pendekatan pemecahan masalah yang menuntun dalam penetapan keperawatan yang komprehensif. Melalui penerapan model adaptasi Roy dalam memberikan asuhan keperawatan, menjadi mediator dalam pencapaian peran sebagai perawat spesialis anak.

Aplikasi model adaptasi Roy perlu lebih banyak digunakan dalam penelitian keperawatan anak. Penerapan asuhan keperawatan komprehensif yang dikombinasikan dengan penerapan evidence based practice akan meningkatkan mutu asuhan keperawatan. 
Desak Putu Kristian Purnamiasih, Nani Nurhaeni, Siti Chodidjah

Aplikasi Model Adaptasi Roy Pada Anak Dengan Gangguan Keseimbangan Cairan

\section{DAFTAR PUSTAKA}

Begum, J.A., Hoque, M.M., Hussain, M., Hasan, M.N.A., \& Molla, M.H. (2010). Impact of electrolyte disturbances in outcome of acute diarrhoea in children. DS(Child) H J, 26 (1), 36-40.

Behrman, R.E., Kliegman, R.M., \& Arvin, A.M. (2000). Ilmu kesehatan anak. (A. Samik Wahab, penerjemah). Jakarta: EGC.

Bilal, S.H., Badr, B.S.H., \& AlAtiyyat, N.M.H. (2014). The relationship between pain experience and Roy adaptation model: Application of theoretical framework. Middle East Journal of Nursing, 8(1).

Christensen, P.J., \& Kenney, J.W. (2009). Proses keperawatan: Aplikasi model konseptual ( Yuyun Yuningsih, Yasmin Asih, Penerjemah). Jakarta:EGC.

Dey, S.K., Chisti, M.J., Das, S.K., Shaha, C.K., Ferdous, F., Farzana, F.D., ...Salam, M.A. (2013). Characteristics of diarrheal illnesses in non-breast fed infants attending a large urban diarrheal disease hospital in Bangladesh. www.plosone.org

Gangaraj, S., Das, G., \& Madhulata, S. (2013). Electrolytes and blood sugar changes in severely acute malnourished children and its association with diarrhoea and vomiting. International Journal of Pharmaceutical Science Invention, 2(5), 33-36.

James, S. R., Nelson, K. A., \& Ashwill, J. W. (2013). Nursing care of children. Fourth Edition. Missouri:Elsevier.
Lamberti, L.M., Walker, C.L.F., Noiman, A., Victora, C., \& Black, R.E. (2011). Breastfeeding and the risk for diarrhea morbidity and mortality.

http://www.biomedcentral.com/1 471-2458/11/S3/S15.

Munos, M.K., Walker, C.L.F., \& Black, R.F. (2010). The effect of oral rehydration solution and recommended home fluids on diarrhoea mortality. International Journal of Epidemiology, 39, i75-i87.

Potts, N.L., \& Mandleco, B.L. (2012). Pediatric nursing: Caring for children and their families. (3rd ed.). Canada:Delmar.

Silbernagl, S., \& Lang, F. (2013). Teks dan atlas berwarna: Patofisiologi. Jakarta:EGC.

Tomey, A. M. \& Alligood, M. R. (2010). Nursing theorist and their work. (seventh ed). Missouri:Mosby Elsevier.

Whittemore, R., Jaser, S., Guo., J., \& Grey, M. (2010). A conceptual model of childhood adaptation to type 1 diabetes. Nurs Outlook, 58(5), 242-251.

Wilkinson, J.M., \& Ahern, N.R. (2009). Buku saku diagnosis keperawatan (Esty Wahyuningsih, Penerjemah). Jakarta:EGC.

Wong, L. D., Hockenberry, M., Willson, D., Winkelstein, M., \& Schwartz, P. (2009). Buku ajar keperawatan pediatrik (Agus Sutarna, Eni Juniarti \& H.Y Kuncara, Penerjemah). Jakarta:EGC. 